Journal of English Language Teaching

\title{
Students' perception on the use of android-based exam browser to assess final examination
}

\section{Prahda Alifa Fegasanti $^{\bowtie 1}$, Arif Suryo Priyatmojo ${ }^{2}$}

English Department, Faculty of Languages and Arts, Universitas Negeri Semarang, Indonesia

\begin{tabular}{l} 
Article Info \\
\hline Article History: \\
Received in 7 \\
Agustus 2020 \\
Approved in 29 \\
November 2020 \\
Published in 30 \\
November 2020 \\
\hline Keywords: Students' \\
perception; Android- \\
based Exam Browser; \\
Exam Browser; Final \\
Examination
\end{tabular}

\begin{abstract}
This study aims to find out the students' perception toward the use of Androidbased Exam Browser as the medium to assess final examination. Android based Exam-Browser is one of the secured web browsers for conducting online examination. This study is conducted since there are still limited research that is conducted in Indonesia which analyses the students' perception toward the implementation of online examination by using Android. This study was employed qualitative survey design in which the data of the students' perception on the use of Android based Exam Browser as the medium to assess final examination were obtained by questionnaire, interview, and also observation. This research shared questionnaires to 33 students. The questionnaire was a close-ended question. Based on the findings of the study, $75,8 \%$ of the students give a positive perception about Android based Exam Browser. The students believed that Android based Exam Browser was a useful, clear, and understandable platform for conducting online examination and it gave some positive impacts such as improving students' speed in answering the questions, improving students' performance in the test, and helping them to answer the exam easily.
\end{abstract}




\section{INTRODUCTION}

The development of information and communication technology from the future increasingly facilitates human needs. Along with the development of the age of technology increasingly role and benefit almost in all fields, including education. There are several factors that must be considered to improve the quality of education, one of which is students' learning achievement.

Learning achievement is the result achieved by a person after he makes learning changes, both at school and outside of school. Winkel (1996) argues that learning achievement is evidence of success that has been achieved by someone. Meanwhile, according to Gunarso (1993) suggests that learning achievement is the maximum effort achieved by someone after carrying out learning efforts. Therefore, Nasution (1996) argues that learning achievement is the perfection of a student in thinking, feeling and doing. So, learning achievement is the maximum result achieved by someone after carrying out learning efforts. Learning achievement can be measured through tests which are often known as learning achievement tests. According to Saifudin (2005), the test of learning achievement when viewed from the objective is to reveal a person's success in learning. In the world of education, exams are an effective way to measure the level of student achievement in schools, such as the Daily Examination, Mid-Semester Examination, and Final Semester Examination.

In the 2014/2015 academic year there was a new policy that exams are carried out in two ways by a written mechanism or Paper Based Test (PBT) or can be carried out with a computer-based mechanism or what is known as the Computer Based Test (CBT). Paper-Based Test (PBT) has many shortcomings in the preparation of test material, multiplication and distribution of question scripts, cheating during the test, requires a lot of cost, energy, time (Clariana \& Wallace, 2002). With the development of technology at this time, one way to deal with the problem of the invalidity of the assessment is that the implementation of the national examination no longer uses the paper-based test system but uses the computer-based national examination system or Computer Based Test (CBT). Computer Based Test (CBT) is a test implementation system using computer media, android, and iOS (Akasheh, 2000). Applications that can be used to carry out this test are HTML applications that can be used for applications on the OS, for example Android, iOS and all computer operating systems, which is very important to use this application we need a web browser, for example Google Chrome, etc.

Currently, to optimize the use of information and communication technology in the world of education, several schools have begun to use devices (Android) to carry out online-based exams. Android based Exam-Browser is one of the secured web browsers for conducting online examination. It works in lock mode, so it prevents opening of any page, switching to unnecessary programs, operating system-specific key combinations and functions, leaving the browser secure at any time and opening gallery (Putra \& Pamungkas, 2020). Therefore, the use of the browser-based android exam is expected to minimize the opportunities for students to cheat (Putra, Maulana, \& Iriani,2019). Android based Exam Browser system is considered very beneficial with a realistic process, saving costs and time (Chikmah, 2016).

A large body of research has been carried out to find out the use of Computer based Test to support the current study. The first study related to this article is a study conducted by Chikmah (2016) entitled "Students' Perception on Proprofs Online Computer-Based Assessment Software as An Assessment Tool at English Education Departement, UIN Sunan Ampel Surabaya". The aim of the study was to determine the students' perception and the result score towards the use of ProProfs online CBA (Computer Based Assessment) Software as an assessment tool. The finding of this research is there were $93 \%$ from the positive component and $7 \%$ from the negative component. It means that the students' perception was positive about Proprofs online computer as assessment tool. In addition, the conclusion of this study could give evaluation for the lecturer who uses ProProfs. The previous studies conducted by Chikmah (2016) was focused in the use of Android based exam regarding the compatibility of a mobile phone, self-efficacy, and perceived ease of use. In this study, it not only focus on the compatibility of a mobile phone, self-efficacy, and perceived ease of use but also focus on knowing the students' intention, anxiety and also Android's attitude towards using CBT using Android based Exam Browser.

The second study related to this article is a study by by Nugroho, Kusumawati and Ambarwati (2018) entitled "Students' Perception on the use of Computer Based Test". This research filled the void in the literature by offering the experience of the students on the two evaluation methods (CBT and PPT). The aim of the study was to determine the students' perception on the use of Computer Based Test (CBT).The finding of this research was 31\% of students that using CBT as their final exam 
prefers to use CBT as the means to conduct a test. Meanwhile only $34 \%$ of them were disagree of CBT usage for conducting a test. The other students have neutral opinion towards the CBT test $(35 \%)$. This previous studies was focused on students 'perceptions regarding whether or not to use CBT for exams without exploring students' perceptions of performance as well as the drawbacks of using CBT. This study will fill the gap in the literature by providing students' perceptions of focusing on the advantages and disadvantages of using CBT based Exam Browser by using Android.

This present study is conducted based on theory of perception (Koentjaningrat, 1985) about the alignment of factors in the expression of perceptions such as feelings, needs, motivation, educational background and experiences which strongly related to a sense of organs (Walgito, 2004). Meanwhile, to determine the outcome of perception, theories that related to the types of perceptions (Robbins, 2002; Sarwono, 2002) to classified as positive perceptions or negative perceptions are used in this study. Additionally, in relation to CBT (Computer Based Test) knowledge, theories that related to the definition of CBT by using Android-based Exam Browser (James, 2018; Sarrayrih\&Ilyas, 2013), and key features of Android-based Exam Browser (William, 2012) are used in this study.

In terms of perception (Koentjaningrat, 1985) explained that perception is a re-alignment of the human brain process and appears to be a phenomenon view many factors, such as feelings, needs, motivation, educational background and experience that are involved in this process. Then the process is followed by a process which a person's brain arrives at meaningful perception of stimuli. Furthermore, the stimulus can arrive from outside and inside of the individual (Walgito, 2004).In addition, Sarwono (2002) clarified that perception could be a way of feeling happy or unhappy that can be classified as positive perceptions and negative perceptions. Positive perception plays a role in our senses that we continue to like or support a specific object. On the other hand, negative perception is a perception where a person tends to dislike or not support something. Moreover, Robbins (2002) described positive perception is an individual opinion about an object or information with an outlook, or the information is the same as that predicted by an person. Meanwhile, negative perception is an individual perception that has a negative perspective on an object or specific knowledge that is different from the individual's expectations. The dissatisfaction of a human with an object is the source of negative perception.

In terms of the definition of CBT by using Android-based Exam Browser (Sarrayrih \& Ilyas, 2013) stated that Exam Browser is a Knowledge Management Program for Quizzes, Tests, Practice, Flashcards and Information Bases. Exam Browser is an application that is packaged in All in One Moodle CBT or AIOCBT mode which is a program to run computer-based exams but can also be accessed using Android/iOS.The benefit of students using mobile devices when conducting examinations is that they are more flexible because they do not need cable networks (Sarrayrih and Ilyas, 2013). Moreover, Android Kiosk is basically a gadget or smartphone that is intended to run a single application and to serve certain cases. Some basic requirements to be in kiosk mode include the need to be in a single mode serving specific use cases, hiding navigation, removing the toolbar, controlling or blocking all ways of setting it to the smartphone, turning off calls or messages according to the use case and the application must continue to run in mode full screen (James, 2018). The key features of this application used is Lockdown application that is a computer program used during an online exam that attempts to prevent users from accessing software other than the exam application. The application will lock the online exam environment in a classroom or through an actor; prevent access to applications and other websites during the exam; prevent test takers from copying or printing exam content; as well as displaying the contents of the exam in full screen and cannot be minimized (William, 2012) so it can be helpful for less cheating by the students.

However, due to the negative perceptions that arise from the results of previous study, this motivates me to know more about how the students' feel about the implementation of Android-based exams. On the other hand, because there are pros and cons related to the implementation of this online-based exam, this research is very important because students' perceptions are the main source for knowing and measuring the effectiveness of using Android as a medium for implementing online exams. This study is intended to find out students' perception on the use of Android based Exam Browser as the medium to assess final examination.

\section{METHODS}

In this study, the researcher uses a descriptive qualitative method as her research methodology. In a qualitative method, it utilizes certain methodologies and procedures to generate qualitative data in the forms of words, either spoken or written (Nahdia,2017). Denzin \& Lincoln (2008), defines "qualitative 
research involves an interpretive and naturalistic approach means that qualitative researchers study things in their natural settings, attempting to make sense of, or to interpret, phenomena in terms of the meanings people bring to them". In other words, qualitative research tends to obtain the meanings, perception, explanation, and sensations. Also, one fundamental characteristic of qualitative method is naturalistic data involvement (Sumpada,2019). So, this research method attempts to study language learning and teaching in their naturally occurring setting without any intervention or manipulation of variables.

This study was employed qualitative survey design in which the data of the students' perception on the use of Android based Exam Browser as the medium to assess final examination were obtained by questionnaire, interview, and also observation. Ary et al (2018) state that survey is a researcher's technique in which data are gathered by asking questions on a group of individuals called respondents. Moreover, Wiersma (1995) states that surveys are used to measure attitudes, opinions, or achievements in any number of variables in natural settings. In addition, according to Arikunto (2010), a combination of various data resources and methods (multi data collection methods) is the appropriate method for qualitative study. For that reason, in this study, the researcher did some data collection methods such as observation, interview, questionnaire, and also documentation for having a complete data collection.

This research was arranged in academic year 2019/2020. Firstly, the researcher asking permission from the school's area. After the researcher get permission from the headmaster, the researcher makes an appointment with teachers for the observation in class which already doing the examination by using Android based Exam Browser. Furthermore, during the data collecting methods, the researcher also documented the implementation of Android-based exams. After did the observation, the researcher distributing the questionnaire to the students in that class. Then, to obtain more in-depth information, the researcher was gathering the students in one room, and call them one by one in turn to conduct interview.

After analyzing the texts, the researcher presented the results by using tables. Then, the results were put into the discussion part in order to discuss and review the students' perception on using Android based Exam Browser as the medium to conduct examination. The data gathered from the questionnaire were analyzed by the most frequent degree of agreement chosen as the way to summarize the data in a frequency distribution and calculate all the scores of each statement and process the total scores as the result in percentage. The data gathered from interview were analyzed by changing and describing the interview answers in text form, and it analyzed based on predetermined factors, then calculated the results obtained using a percentage. Furthermore, the result of observation was used to support the previous data collected by the questionnaire and presenting together as the finding of the research. After that, the researcher drew the conclusion of the results. In order to know the validity of the data in qualitative research, the triangulation technique is employed. The type of triangulation technique that is chosen is method triangulation. Through different data collection methods, it is expected to obtain results that are close to truth.

\section{FINDINGS AND DISCUSSION}

The findings are presented into five parts; they are the students' interest, students' perception (perceived usefulness), students' perception (perceived ease of use), students' anxiety, and students' Android attitude about the use of Android based Exam Browser as the medium to assess final examination.

\section{Students' interest about Android-based Exam Browser}

According to Ubaidillah (2020), interest is a constant process of paying attention and focusing on something that is of interest to him with feelings of pleasure and satisfaction. Suharyat (2009) stated that interest is a mental device which consists of a mixture of feelings, hopes, convictions, prejudices, fears or other tendencies that lead the individual to a particular thought. In simple terms, interest (interest) means a tendency and high excitement or a great desire for something. Abror (1993) said that interest can relate to the power of movement that encourages us to tend or feel attracted to people, objects, or activities or it can be an effective experience stimulated by the activity itself. In other words, interest can be a cause of activity and a cause of participation in activities. The table below shows the students' interest about Android-based Exam Browser. 
Table 1. Students' interest about Android-based Exam Browser

\begin{tabular}{lcc}
\hline \multicolumn{1}{c}{ Item Description } & Agree & Percentage \\
\hline $\begin{array}{l}\text { Factor 1 - Intention } \\
\text { 1. By using the Android based Exam Browser system in the exams, I was } \\
\text { able to answer the questions more quickly compared to a paper-based } \\
\text { exam. }\end{array}$ & 27 & $82 \%$ \\
$\begin{array}{l}\text { 5. Android based Exam Browser system enabled me to take exams } \\
\text { easily. }\end{array}$ & 26 & $79 \%$ \\
$\begin{array}{l}\text { 12. Using the Android based Exam Browser system to take exams was a } \\
\text { good idea. }\end{array}$ & 22 & $67 \%$ \\
$\begin{array}{l}\text { 13. Using the Android based Exam Browser system to take exams was a } \\
\text { wise idea. }\end{array}$ & 23 & $70 \%$ \\
$\begin{array}{l}\text { 14. I liked the idea of using the Android based Exam Browser system. } \\
\text { 15. Using the Android based Exam Browser system was pleasant. } \\
\text { 16. The Android based Exam Browser system provided an attractive } \\
\text { exam environment. }\end{array}$ & 20 & $61 \%$ \\
$\begin{array}{l}\text { 17.I found using the Android based Exam Browser system enjoyable. } \\
\text { 18.In general, I was positive toward Android based Exam Browser }\end{array}$ & 21 & $79 \%$ \\
system. & 25 & $76 \%$ \\
$\begin{array}{l}\text { 19.I intend to take courses that use the Android based Exam Browser in } \\
\text { the future. }\end{array}$ & 22 & $82 \%$ \\
\hline
\end{tabular}

In this study, the researcher can conclude that the students believe that the use of Android based Exam Browser as the medium to assess final examination is a good system for test. It can be proven by the result of questionnaire that $72 \%$ of the students give a positive perception about the use of Android based Exam Browser system. It is also in line with Chikmah (2016) statement that says Computer based Test is a good and enjoyable system for conducting online examination. The students believe that the use of Android based Exam Browser can improve the students' speed in answering the questions and can make the exam easily. They also believe that Android based Exam Browser is an attractive and enjoyable system and a good and wise idea from school which already implemented Android based Exam Browser system.

\section{Students' perception (perceived usefulness) about Android-based Exam Browser}

Information systems will be said to be effective if users believe that using information systems will improve their performance and believe that using information systems will make their efforts easier (Wixom and Todd, 2005). This is a certain perception and leads to user beliefs about information systems that affect the benefits they feel (Wixom and Todd, 2005). According to Davis (1993) and AlGahtani (2001) the usefulness of information systems (Perceived usefulness) is the extent to which an individual believes that using a particular system will improve performance. Meanwhile, according to Gong and $\mathrm{Xu}$ (2004) the definition of perceived usefulness is the subjective probability that users using certain application systems can increase their expectations. The table below shows the students' perception (perceived usefulness) about Android-based Exam Browser.

Table 2. Students' perception (perceived usefulness) about Android-based Exam Browser

\begin{tabular}{lcc}
\hline \multicolumn{1}{c}{ Item Description } & Agree & Percentage \\
\hline $\begin{array}{l}\text { Factor 2 - Perceived Usefulness } \\
\begin{array}{l}\text { 2.Using Android based Exam Browser system improved my } \\
\text { performance in the exam. }\end{array}\end{array}$ & 19 & $58 \%$ \\
$\begin{array}{l}\text { 4.Using Android based Exam Browser system enhanced my } \\
\text { effectiveness in the course. }\end{array}$ & 17 & $52 \%$ \\
$\begin{array}{l}\text { 20.I wish I used the Android based Exam Browser system for other } \\
\text { courses as well. }\end{array}$ & 18 & $55 \%$ \\
\hline
\end{tabular}

In this study, the researcher can conclude that the students believe that the use of Android based Exam Browser as the medium to assess final examination is perceived usefulness. It can be proven by 
the result of questionnaire that $55 \%$ of the students give a positive perception about the use of Android based Exam Browser system. The students believe that the use of Android based Exam Browser can improve the students' performance in the test, and they also believe that Android based Exam Browser is an effective system for assessing exam.

\section{Students' perception (perceived ease of use) about Android-based Exam Browser}

According to Ndubisi et al. (2003) perceived ease of use refers to how clear and understandable, interaction with the system is ease of getting the system to do what is require, mental effort required to interact with the system and ease of use of the system. Refers to how the interaction is clear and easy to understand on the information system used, the ease of getting the information system to do what is needed, the mental effort required to interact with the system and the ease of use of the information system (Ndubisi et al., 2003). The table below shows the students' perception (perceived ease of use) about Android-based Exam Browser.

Table 3. Students' perception (perceived ease of use) about Android-based Exam Browser

\begin{tabular}{|c|c|c|}
\hline Item Description & Agree & Percentage \\
\hline Factor 3 - Perceived ease of use & & \\
\hline 3. I found the Android based Exam Browser system useful. & 26 & $79 \%$ \\
\hline $\begin{array}{l}\text { 6. I think the Android based Exam Browser system was useful in all } \\
\text { course. }\end{array}$ & 23 & $70 \%$ \\
\hline $\begin{array}{l}\text { 7. Learning to use the Android based Exam Browser system was } \\
\text { hard for me. }\end{array}$ & 14 & $42 \%$ \\
\hline $\begin{array}{l}\text { 8. My interaction with the Android based Exam Browser was clear } \\
\text { and understandable. }\end{array}$ & 21 & $64 \%$ \\
\hline $\begin{array}{l}\text { 9. My interaction with the Android based Exam Browser system did } \\
\text { not require a lot of mental effort. }\end{array}$ & 20 & $61 \%$ \\
\hline 10. I found the Android based Exam Browser system easy to use. & 31 & $94 \%$ \\
\hline $\begin{array}{l}\text { 11. It was easy to navigate through the Android based Exam } \\
\text { Browser system. }\end{array}$ & 22 & $67 \%$ \\
\hline $\begin{array}{l}\text { 31. I felt comfortable when using the Android based Exam Browser } \\
\text { system on my own. }\end{array}$ & 18 & $55 \%$ \\
\hline $\begin{array}{l}\text { 32. I was able to use the Android based Exam Browser system even } \\
\text { if there was no one around show me how to use it. }\end{array}$ & 18 & $55 \%$ \\
\hline $\begin{array}{l}\text { 33. I was confident that I had adequate ability to operate the } \\
\text { Android based Exam Browser system. }\end{array}$ & 22 & $67 \%$ \\
\hline $\begin{array}{l}\text { 34. I was confident that I could use the Android based Exam } \\
\text { Browser system even if I had no prior experience on similar systems. }\end{array}$ & 17 & $52 \%$ \\
\hline $\begin{array}{l}\text { 35. I could use the Android based Exam Browser system if an } \\
\text { assistant showed me how to do it first. }\end{array}$ & 29 & $88 \%$ \\
\hline
\end{tabular}

In this study, the researcher can conclude that the students believe that the use of Android based Exam Browser as the medium to assess final examination was an easy tool system for test. It can be proven by the result of questionnaire that $66 \%$ of the students give a positive perception about the use of Android based Exam Browser system. The students believe that the use of Android based Exam Browser was useful, clear and understandable, easy to use and navigate. Rogers (2010) stated that perceived ease of use demonstrates the degree to which an invention is seen as being no too difficult to understand, learn or operate). The students also believe that they were confident to used Android based Exam Browser even if they had no prior experience on similar system.

\section{Students' anxiety about Android-based Exam Browser}

Johnston (1991) argues that anxiety is a reaction to threats, obstacles to personal desires, or a feeling of distress because of disappointment, dissatisfaction, insecurity, or hostility to others. Furthermore, Deese, Lazarus, \& Keenan (1953) divides anxiety into two senses, namely anxiety as a response and as an intervening variable. Anxiety as a response is divided into two, namely state anxiety and trait anxiety. State anxiety is the symptoms of anxiety that arise when the individual is exposed to certain situations that are perceived as threatening. This level of anxiety depends on the intensity of the stimulus that affects it, meaning that the individual will experience anxiety as long as the condition exists. Trait anxiety is anxiety that remains in a person. This anxiety has been integrated into the 
personality so that individuals who have this anxiety are more likely to become anxious when they face situations that are considered threatening themselves. The table below shows the students' anxiety about Android-based Exam Browser.

Table 4. Students' anxiety about Android-based Exam Browser

\begin{tabular}{lcc}
\hline Item Description & Agree & Percentage \\
\hline $\begin{array}{l}\text { Factor } 4 \text { - Anxiety } \\
\begin{array}{l}\text { 21. The Android based Exam Browser system was somewhat } \\
\text { intimidating to me. }\end{array}\end{array}$ & 16 & $48 \%$ \\
$\begin{array}{l}\text { 22. I hesitated to use the Android based Exam Browser system for } \\
\text { fear of making mistakes that I couldn't correct. }\end{array}$ & 21 & $64 \%$ \\
$\begin{array}{l}\text { 23. I felt anxious about using the Android based Exam Browser } \\
\text { system. }\end{array}$ & 18 & $55 \%$ \\
$\begin{array}{l}\text { 24. Working with the Android based Exam Browser system made } \\
\text { me nervous. }\end{array}$ & 19 & $58 \%$ \\
\hline
\end{tabular}

In this study, the researcher can conclude that the students believe that the use of Android based Exam Browser as the medium to assess final examination make students have a sense of anxiety. It can be proven by the result of questionnaire that most of the students give a negative perception about the use of Android based Exam Browser system. The students believe that the use of Android based Exam Browser creates anxiety for students. This finding is in line with research findings of Nahdia (2017) which proved that exams put pressure on students due to fear, panic, and fatigue. This anxiety is seen as a symptom, which means a condition that shows difficulty in carrying out the adjustment process. Computer anxiety can take the form of experiences of unknown fear, feelings of frustration, failure and disappointment, and unpleasant feelings (Orr, 2002). They feel intimidated, anxious, nervous and scared by the use of Android as a medium for exams.

\section{Students' Android attitude about Android-based Exam Browser}

Chart 5. Students' Android attitude about Android-based Exam Browser

\begin{tabular}{lcc}
\hline \multicolumn{1}{c}{ Item Description } & Agree & Percentage \\
\hline $\begin{array}{l}\text { Factor 5 - Android Attitude } \\
\text { 25. It was comfortable to work with the Android based Exam }\end{array}$ & 21 & $64 \%$ \\
$\begin{array}{l}\text { Browser system. } \\
\text { 26. Computer Based Test (CBT) based Android are bringing us } \\
\text { into a bright new era. }\end{array}$ & 25 & $76 \%$ \\
$\begin{array}{l}\text { 27. The use of computers Based Test (CBT) based Android is } \\
\text { enhancing our standard of living. }\end{array}$ & 26 & $79 \%$ \\
$\begin{array}{l}\text { 28. There are unlimited possibilities of computer applications that } \\
\text { have not even been thought of yet. }\end{array}$ & 27 & $82 \%$ \\
$\begin{array}{l}\text { 29. Computers Based Test (CBT) based Android are responsible } \\
\text { for many of the good things we enjoy. }\end{array}$ & 19 & $58 \%$ \\
$\begin{array}{l}\text { 30. Working with computers Based Test (CBT) based Android is } \\
\text { an enjoyable experience. }\end{array}$ & 24 & $73 \%$ \\
\hline
\end{tabular}

In this study, the researcher can conclude that the students believe that the use of Android based Exam Browser as the medium to assess final examination is a good system for test. It can be proven by the result of questionnaire that $71 \%$ of the students give a positive perception about the use of Android based Exam Browser system. The students believe that the use of Android based Exam Browser can brought them into a bright new era, enhanced their standard of living and they also believe that Android based Exam Browser is an enjoyable system. The students also believe that Android based Exam Browser is responsible for many of the good things such as saves paper and stationery, savings cost, and summarizing tasks for correction for teachers.

\section{CONCLUSION}

The students' perception on the use of Android based Exam Browser as the medium to assess final examination was positive. The students believed that Android based Exam Browser is an attractive 
and enjoyable system or platform to assess final examination. It can be proven by the result of questionnaire that $75,8 \%$ of the students give a positive perception about Android based Exam Browser. The students believed that Android based Exam Browser was a useful, clear, and understandable platform for conducting online examination and it gave some positive impacts such as improving their speed in answering the questions, improving their performance in the test, and helping them to answer the exam easily. Besides the positive perception about the use of Android based Exam Browser as the medium to assess final examination there were also the negative perception. The 57,6\% students believed that using the Android-based Exam Browser was somewhat intimidating to them because not all students used Android with enough internal memory to install these applications. The students also feel afraid of making mistakes in using Android based exam because sometimes the application is often slow and even suddenly exit from the application. The use of Android based Exam Browser not only makes the students afraid, but also anxious and nervous due to sometimes their Android not as friendly as hangs, runs out of battery, and disconnected from the connection server.

We suggest that the use of Android based Exam Browser can be continued for further exams because students believe that the Android based Exam Browser is an effective platform or application for conducting Android based online examination. Therefore, the school should improve this Android based examination platform by increasing the number of internet servers and improving the site in the application.

\section{REFERENCES}

Abror, A. R. (1993). Psikologi pendidikan. Yogyakarta: Tiara Wacana.

Akasheh, H. F. (2000, October 17). Computer based test operating system. Patent and Trademark Office. Retrieved from https://www.uspto.gov/

Al-Gahtani, S. (2001). The applicability of TAM outside North America: An empirical test in the United Kingdom. Information Resources Management Journal (IRMJ), 14(3), pp. 37-46.

Arikunto, S. (2010). Metode Peneltian. Jakarta: Rineka Cipta.

Ary, D., Jacobs, L. C., Irvine, C. K. S., \& Walker, D. (2018). Introduction to research in education. Cengage Learning.

Asih, V., Saputra, A., \& Subagio, R. T. (2020). Penerapan Algoritma Fisher Yates Shuffle untuk Aplikasi Ujian Berbasis Android. Jurnal Digit, 10(1), pp. 59-70.

Chikmah, Lailatul. (2006). Students' perception on Proprofs Online Computer-Based Assessment Software as Assessment Tool at English Education Department (Unpublish master's thesis). Universitas Islam Negeri Sunan Ampel, Surabaya, Indonesia.

Clariana, R., \& Wallace, P. (2002). Paper-based versus computer-based assessment: key factors associated with the test mode effect. British Journal of Educational Technology, 33(5), pp. 593-602.

Davis, F. D. (1989). Perceived usefulness, perceived ease of use, and user acceptance of information technology. MIS quarterly, pp. 319-340.

Deese, J., Lazarus, R. S., \& Keenan, J. (1953). Anxiety, anxiety reduction, and stress in learning. Journal of Experimental Psychology, 46(1), pp. 55.

Denzin, N. K., \& Lincoln, Y. S. (2008, June 18). Introduction: The discipline and practice of qualitative research. Retrieved from https://psycnet.apa.org/record/2008-06339-001

Gall, M., Gall, J., \& Borg, R. (2007). Educational research: An introduction (8th ed.). New York, NY: Pearson Education.

Gong, M., Xu, Y., \& Yu, Y. (2004). An enhanced technology acceptance model for web-based learning. Journal of Information Systems Education, 15(4), pp.126-128.

Gunarso, A. (1993). Bagaimana Bimbingan dan Penyuluhan Belajar di Sekolah. Surabaya: Usaha Nasional.

James, K. (2018, June 19). Kiosk Mode. Retrieved from https://technostacks.com/blog/androidkiosk-mode/

Johnston, A. L., \& File, S. E. (1991). Sex differences in animal tests of anxiety. Physiology \& behavior, 49(2), pp. 245-250.

Koentjaraningrat, K. (1985). Javanese culture. London: Oxford University Press.

Lestari, M. A. M. (2020). Teachers' reinforcement and students' perception to the teachers in English classroom. ELT Forum: Journal of English Language Teaching, 9(1), pp. 96-106).

Nahdia, K. (2017). Washback Analysis of Students' Perception and Teachers' Teaching Material of English National Examination. ELT Forum: Journal of English Language Teaching, 6(1), pp. 92-101. 
Nasution, S. (1996, March 22). Prestasi Belajar. Retrieved from http://eprints. uny. ac. id/9434/2/bab, 202.

Orr, S. P., Metzger, L. J., \& Pitman, R. K. (2002). Psychophysiology of post-traumatic stress disorder. Psychiatric Clinics, 25(2), pp. 271-293.

Putra, E. Y., \& Pamungkas, S. (2020). Implementasi Pelaksanaan Ujian Semester Berbasis Android dalam Mata Pelajaran Sejarah di SMA Negeri 3 Kota Jambi.ISTORIA: Jurnal Ilmiah Pendidikan Sejarah Universitas Batanghari, 4(1), pp. 32-41.

Putra, R. L., Maulana, A., \& Iriani, T. (2019). Evaluasi Program Pelaksanaan Ujian Online Dengan Menggunakan Learning Management System Moodle Berbasis Android Di SMK Negeri 1 Jakarta. Jurnal Pensil: Pendidikan Teknik Sipil, 8(1), pp. 47-54.

Robbins, S. P. (2002). Prinsip-prinsip perilaku organisasi. Jakarta: Erlangga.

Saifudin, A. (2005, Mei 23). Pengertian Prestasi Belajar. Retrieved from http://Pengertian Prestasi Belajar «FASILITATOR IDOLA. htm

Sarrayrih, M. A., \& Ilyas, M. (2013). Challenges of online exam, performances and problems for online university exam. International Journal of Computer Science Issues (IJCSI), 10(1), pp. 439.

Sarwono, S. W. (2000). Pengantar Umum Psikologi. Jakarta: Bulan Bintang.

Suharsimi Arikunto. (1996). Prosedur Penelitian Suatu Pendekatan Praktek. Jakarta: Rineka Cipta.

Suharyat, Y. (2009). Hubungan antara sikap, minat dan perilaku manusia. Jurnal Region, 1(3), pp. 119.

Sumpada, A. I. (2019). Investigating Washback of National Standardized School Examination on Junior High School Students and Teachers. ELT Forum: Journal of English Language Teaching 8(2), pp. 158-165.

Ubaidillah, U. (2020). Pengembangan Minat Belajar Kognitif Pada Anak Usia Dini. JCE (Journal of Childhood Education), 2(2), pp. 41-65.

Walgito, B. (2004). Hubungan antara persepsi atas dukungan organisasi dan kualitas hubungan atasanbawahan dengan komitmen dan perilaku keanggotaan (Doctoral dissertation). Universitas Gadjah Mada, Yogyakarta, Indonesia.

Wiersma, W. (1985, July 29). Research methods in education: An introduction.Retrieved from http://www.sidalc.net/cgibin/wxis.exe/?IsisScript=UADY.xis\&method=post\&formato=2\&ca ntidad $=1 \&$ expresion $=\mathrm{mfn}=003185$

William, H. (2012, August 22). What is Lock Down Browser. Retrieved from https://www.igiglobal.com/dictionary/technological-approaches-maintaining-academic-in-tegrity/17447

Winkel, W. S., \& Pengajaran, P. (1996). Cet. IV. Jakarta: Grasindo.

Wixom, B. H., \& Todd, P. A. (2005). A theoretical integration of user satisfaction and technology acceptance. Information systems research, 16(1), pp. 85-102. 